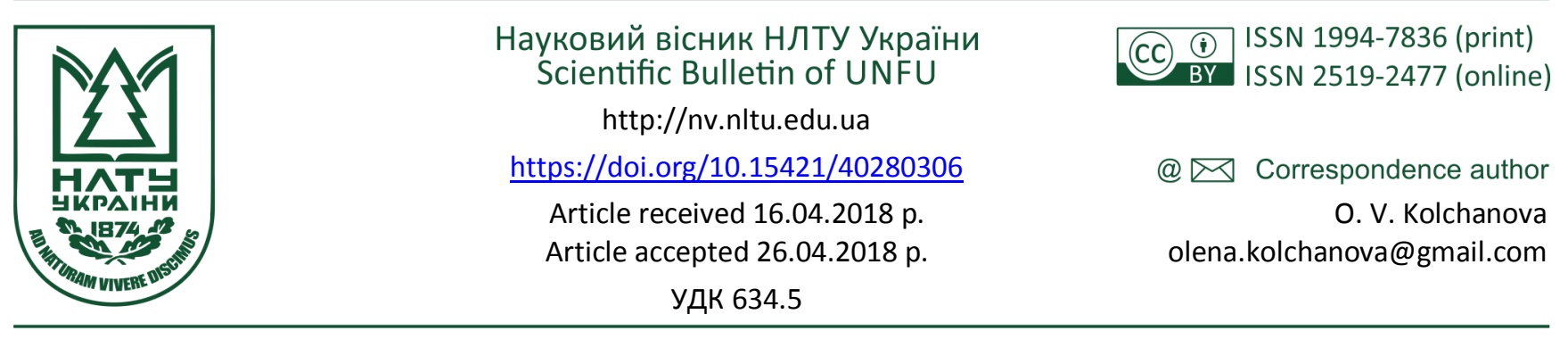

О. В. Колчанова

ДП "Віннищька лісова науково-дослідна станція" УкрНДІЛГА, м. Віннищя, Украӥна

\title{
РЕЗУЛЬТАТИ ПРИЖИВЛЮВАНОСТІ СОРТІВ ФУНДУКА ПІД ЧАС ЗЕЛЕНОГО ЖИВЦЮВАННЯ У ТЕПЛИЦЯХ ІЗ ТУМАННИМ ЗРОШЕННЯМ В УМОВАХ ВІННИЧЧИНИ
}

\begin{abstract}
Досліджено особливості приживлюваності сортів фундука шляхом зеленого живцювання. Використано 12 сортів фундука української селекції, які відрізнялися за морфологічними особливостями та рівнем плодоношення в умовах дендропарку Харківського національного аграрного університету. Досліджено сорти: 'Боровський', 'Велетень', 'Дохідний', 'Клиновидний', 'Краснолистий', 'Лозівський булавовидний', 'Лозівський шаровидний', 'Олімпійський', 'Пірожок', 'Превосходний-2', 'Серебристий', 'Харків-4'. Оцінено вплив речовин-активаторів ризогенезу: "Чаркор" (0,30 \% розчин) та "Grandis" (0,33 \% розчин). Варіанти досліджень також включали попереднє замочування живців у воді та безпосереднє нарізування живців перед закладанням у теплиці. За результатами проведених досліджень встановлено залежність ступеня приживлюваності фундука під час зеленого живцювання від сорту. Найвищий рівень ризогенезу виявлено у сортів 'Харків-4' (64 \%) та 'Краснолистий' (53 \%). Дещо нижчою приживлюваністю та ризогенезом характеризувалися такі сорти, як: 'Боровський', 'Велетень' та 'Олімпійський' (40-50 \%). Низька збереженість була у сортів 'Превосходний-2', 'Лозівський булавовидний' та 'Дохідний' (2-8 \%). Повністю загинули живці сорту 'Серебристий'. Вища приживлюваність за використання препарату "Grandis" була у таких сортів, як 'Клиновидний' та 'Лозівський шаровидний'. Позитивний вплив на сорт 'Харків-4' мав препарат "Чаркор". Більшість сортів позитивно відреагували на попереднє замочування живців у воді.
\end{abstract}

Ключові слова: ризогенез; фундук; сорт; активатори росту; зелене живцювання.

Вступ. Ліщина звичайна (Corylus avellana) - вид дерев'янистих листопадних чагарників роду ліщина родини ліщинові (Corylaceae). Цей чагарник поширений практично по усій території України (Chopyk, Dydchenko \& Krasnova, 1983). Сорти ліщини звичайної отримано шляхом селекційного відбору. Для створення та виведення сортів фундука шляхом гібридизації та наступного відбору використовували переважно ліщину понтійську (Corylus pontiaca) та ліщину великоплоду або ломбардську (Corylus maxima) (Shchepotev et al., 1978).

Морфологічні характеристики та репродуктивну здатність сортів фундука широко вивчали науковці. На жаль, не для всіх сортів наявний детальний морфологічний опис (Kolchanova \& Los, 2014; Los 1992, 1994; Shchepotev et al., 1978).

Розведення та розмноження цінних форм, сортів та гібридів є одним із найактуальніших питань. Ліщину можна розмножувати як насіннєвим, так і вегетативним шляхом (Alihanova, 2009; Balabak, 2015; Ivanova, 1982; Kudasheva, 1965; Los 1992; Sobchenko, 2004). Проте ознаки сортів й інших цінних гібридних форм можна зберегти тільки вегетативним розмноженням.

Упродовж останніх років досить активно використовують регулятори росту рослин під час зеленого живцювання. До таких належать "Чаркор" та "Grandis", які активізують ризогенез (Vasylyuk, Hrytsenko \& Vasylyuk, 2008; Tsyhankova, Ponomarenko \& Halkin, 2012). Виявлено зальний позитивний вплив препарату "Чаркор" на гістогенез коренів під час зеленого живцювання більшості декоративних чагарників (Pinchuk \& Lihanov, 2016; Tsyhankova, Ponomarenko \& Halkin, 2012). Проте вплив цих препаратів, а також методів і способів зеленого живцювання на широкий спектр сортів фундука остаточно ще не з'ясовано. За слабкої здатності фундука до ризогенезу (Balabak, 2015; Bassil et al., 1991) успішність його укорінення більшою мірою залежить від сорту, форми та термінів зеленого живцювання (Alihanova, 2009).

Мета роботи - дослідити здатність укорінення сортів фундука української селекції та визначити найоптимальніші технологічні підходи щодо зеленого живцювання у теплицях із туманним зрошенням.

Об'єкти дослідження - сорти фундука та особливості їх укорінення за використання активаторів росту у теплицях із туманним зрошенням.

Методика дослідження. Заготівлю гілок сортів фундука для зеленого живцювання проводили наприкінці червня 2017 р. у дендропарку ХНАУ ім. В. В. Докучаєва. Розмноження сортів фундука зеленим живцюванням виконували згідно з методикою С. Г. Ванічевої (Vanycheva, 1989). В одному з варіантів досліду живці

\section{Інформація про автора:}

Колчанова Олена Вікторівна, мол. наук. співробітник. Email: olena.kolchanova@gmail.com

Цитування за ДСТУ: Колчанова О. В. Результати приживлюваності сортів фундука під час зеленого живцювання у теплицях із туманним зрошенням в умовах Вінниччини. Науковий вісник НЛТУ України. 2018, т. 28, №3. С. 30-33.

Citation APA: Kolchanova, O. V. (2018). Results of Survival of Hazelnut Varieties with Green Stem Cutting in Greenhouses with Foggy Irrigation in Vinnytsia Region. Scientific Bulletin of UNFU, 28(3), 30-33. https://doi.org/10.15421/40280306 
завдовжки 15-20 см нарізали безпосередньо перед укоріненням. В іншому - занурювали у розчин або воду на 12 год. Дослід з використанням регуляторів росту рослин складався із таких варіантів: оброблення біостимулятором "Чаркор" (0,33 \% розчин); оброблення препаратом "Grandis" (0,30\% розчин) (табл. 1$)$.

Препарат "Grandis" та "Чаркор" застосовано для п'яти сортів. Контроль, який передбачав найпоширеніше у практиці безпосереднє нарізування живців перед висаджуванням використано для усіх наявних дванадцяти сортів. Замочування живців у воді застосовано для семи сортів.

Укорінення живців проводили у теплицях із туманним зрошенням. Як субстрат використано гумусну частину темно-сірого лісового грунту, вкритого шаром піску 3-5 см. Обліки приживлюваності пагонів проводили через 3 місяці. Наприкінці вегетаційного періоду для живців визначали такі показники: 1 - збережений зелений старий листок, без сформованої бруньки; 2 - збережений зелений старий листок та наявна одна брунька; 3 - збережений зелений старий листок та дві бруньки; 4 наявність тільки однієї бруньки, старий листок загинув;

5 - наявність двох бруньок і більше, без старого листка (рис. 1).

Табл. 1. Варіанти щодо використання регуляторів росту та попереднього оброблення живців перед укоріненням у теплиці

\begin{tabular}{|c|l|c|c|c|c|}
\hline $\begin{array}{c}\text { № } \\
\text { 3/П }\end{array}$ & \multicolumn{1}{|c|}{ Сорт } & $\begin{array}{c}\text { "Gran- } \\
\text { dis" }\end{array}$ & $\begin{array}{c}\text { Замочу- } \\
\text { вання у } \\
\text { воді }\end{array}$ & $\begin{array}{c}\text { "Чар- } \\
\text { кор" }\end{array}$ & $\begin{array}{c}\text { Контроль } \\
\text { перед висання } \\
\text { джуванням) }\end{array}$ \\
\hline 1 & Боровський & - & + & - & + \\
\hline 2 & Велетень & - & + & - & + \\
\hline 3 & Дохідний & + & - & + & + \\
\hline 4 & Клиновидний & + & - & + & + \\
\hline 5 & $\begin{array}{l}\text { Краснолис- } \\
\text { тий }\end{array}$ & + & - & + & + \\
\hline 6 & $\begin{array}{l}\text { Лозівський } \\
\text { булавовидний }\end{array}$ & - & + & - & + \\
\hline 7 & $\begin{array}{l}\text { Позівський } \\
\text { шаровидний }\end{array}$ & + & - & + & + \\
\hline 8 & Олімпійський & - & + & - & + \\
\hline 9 & Пірожок & - & + & - & + \\
\hline 10 & $\begin{array}{l}\text { Превосход- } \\
\text { ний-2 }\end{array}$ & - & + & - & + \\
\hline 11 & Серебристий & - & + & - & + \\
\hline 12 & Харків-4 & + & - & + & + \\
\hline \multicolumn{2}{|l|}{ Всього } & 5 & 7 & 5 & + \\
\hline
\end{tabular}

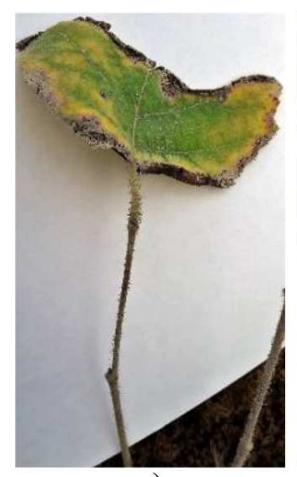

a)

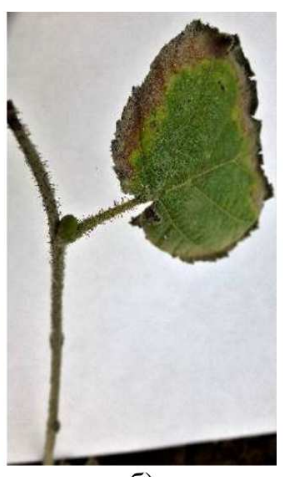

б)

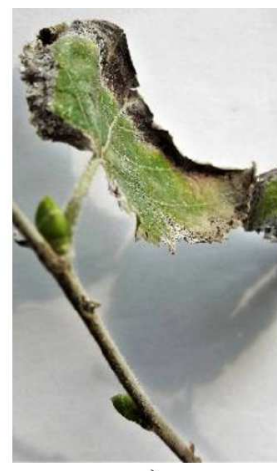

B)

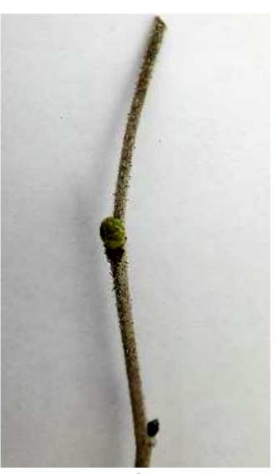

г)

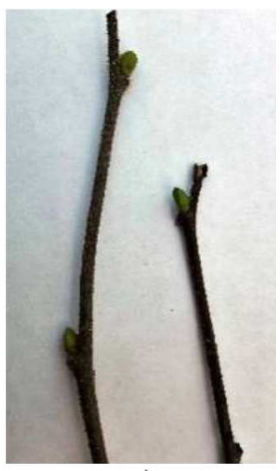

д)

Рис. 1. Характерні приклади приживлюваності сортів фундука у теплиці ДП "Гайсинське ЛГ": а) збережений старий листок; б) збережений старий листок та сформована брунька; в) збережений старий листок та сформовані дві бруньки; г) сформована одна брунька; д) сформовано дві бруньки

Результати досліджень. За результатами проведених досліджень у теплицях із туманним зрошенням встановлено, що ступінь приживлюваності пагонів змінювався у широкому діапазоні - від $0 \%$ до $64 \%$ (табл. 2)

Табл. 2. Результати приживлюваності сортів фундука у теплиці ДП "Гайсинське ЛГ", 2017 р.

\begin{tabular}{|l|c|c|c|}
\hline \multicolumn{1}{|c|}{ Сорт } & $\begin{array}{c}\text { Всього } \\
\text { висадено, } \\
\text { шт. }\end{array}$ & $\begin{array}{c}\text { Приживлюва- } \\
\text { ність } \\
\text { за сортами, шт. }\end{array}$ & $\begin{array}{c}\text { Приживлюва- } \\
\text { ність, \% }\end{array}$ \\
\hline Боровський & 49 & 20 & 40,8 \\
\hline Велетень & 50 & 18 & 36,0 \\
\hline Дохідний & 75 & 6 & 8,0 \\
\hline Клиновидний & 75 & 18 & 24,0 \\
\hline Краснолистий & 75 & 40 & 53,3 \\
\hline $\begin{array}{l}\text { Лозівський } \\
\text { булавовидний }\end{array}$ & 50 & 1 & 2,0 \\
\hline $\begin{array}{l}\text { Лозівський ша- } \\
\text { ровидний }\end{array}$ & 75 & 17 & 22,7 \\
\hline Олімпійський & 50 & 25 & 50,0 \\
\hline Пірожок & 50 & 10 & 20,0 \\
\hline Превосходний-2 & 50 & 1 & 2,0 \\
\hline Серебристий & 50 & 0 & 0,0 \\
\hline Харків-4 & 75 & 48 & 64,0 \\
\hline Всього & 724 & 204 & 28,1 \\
\hline
\end{tabular}

Найвища загальна приживлюваність (50,0-64,0, \%) була у сортів 'Харків-4' (64 \%), 'Краснолистий' (53\%) та
'Олімпійський' (50 \%). Повністю випали такі сорти, як: 'Серебристий', 'Лозівський булавовидний' та 'Превосходний-2'. Збереженість живців значною мірою залежала від варіанта (табл. 3).

Табл. 3. Характеристика приживлюваності сортів фундука у теплиці ДП "Гайсинське ЛГ" із туманним зрошеням за варіантами (\%)

\begin{tabular}{|c|c|c|c|c|c|c|c|}
\hline \multirow[b]{2}{*}{ Варіант } & \multirow{2}{*}{$\begin{array}{c}\text { Старий } \\
\text { листок } \\
\text { без } \\
\text { бруньок }\end{array}$} & \multicolumn{5}{|c|}{$\begin{array}{c}\text { Кількість бруньок, шт. } \\
\text { та наявність листя }\end{array}$} & \multirow{2}{*}{$\begin{array}{l}0 \\
\dot{0} \\
\dot{0} \\
0\end{array}$} \\
\hline & & 1 & 2 & $\begin{array}{c}1 \text { брунь- } \\
\text { ка та } \\
\text { листок }\end{array}$ & $\begin{array}{c}2 \text { брунь- } \\
\text { ки та } \\
\text { листок }\end{array}$ & 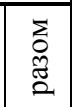 & \\
\hline "Grandis" & 27,2 & 1,6 & 0,0 & 10,4 & 1,6 & 13,6 & 40 \\
\hline "Чаркор" & 8,0 & 8,0 & 3,2 & 4,8 & 2,4 & 18,4 & 26 \\
\hline $\begin{array}{l}\text { Замочуван- } \\
\text { ня у воді }\end{array}$ & ,9 & 8,6 & 0,0 & 5,7 & 2,9 & 17,2 & 24 \\
\hline Контроль & 6,3 & 6,3 & 2,7 & 9,0 & 1,7 & 19,7 & 26, \\
\hline Всього & 10,3 & 6,3 & 1,7 & 7,7 & 2,1 & 17,8 & 28 \\
\hline
\end{tabular}

За даними табл. 3, найкраща приживлюваність (40,8 \%) була в разі використання препарату "Grandis". Приживлюваність сортів фундука за іншими варіантами була у межах 24-26\%. Поряд із цим розвиток ростової бруньки було відзначено тільки у 17,8 \% усіх живців.

Найкраща приживлюваність (19,7 \%) за наявністю життєздатних бруньок була в разі безпосереднього нарізування живців перед висаджуванням (контроль). Із 
загального розподілу, найбільша частка припала на живці із збереженим старим листком (10,3\%). Наявність однієї або двох бруньок була у 6-8 \% рослин відповідно. Найнижча частка живців була із двома бруньками.

На збереження старого листка більшою мірою вплинув препарат "Grandis" (27,2 \%). Позитивний вплив також мав препарат "Чаркор" та замочування у воді (переважання контролю на 1-2 \%). Ці ж варіанти виявилися успішними для формування однієї ростової бруньки. Найістотніший вплив мав препарат "Чаркор" на утворення двох бруньок у живців. Використання препарату "Grandis" мало позитивний ефект для утворення бруньки та збереження старого листка. Частка живців із збереженим листком і двома розвиненими бруньками була більшою за контроль у варіантах із попереднім замочуванням у воді та застосуванням препарату "Чаркор".

У табл. 4 наведено дані стосовно приживлюваності сортів за варіантами відносно контролю.

Табл. 4. Розподіл загальної кількості живців, що прижилися, у розрізі сортів та варіантів порівняно із контролем ("Гайсинське ЛГ", 2017 р. (\%)

\begin{tabular}{|c|c|c|c|c|c|c|c|c|}
\hline \multirow[t]{2}{*}{ Сорт } & \multicolumn{2}{|c|}{ "Grandis" } & \multicolumn{2}{|c|}{$\begin{array}{l}\text { Замочуван- } \\
\text { ня у воді }\end{array}$} & \multicolumn{2}{|c|}{ "Чаркор" } & \multirow{2}{*}{$\begin{array}{l}\text { Кон- } \\
\text { троль }\end{array}$} & \multirow{2}{*}{$\begin{array}{c}\text { Всьо- } \\
\text { го }\end{array}$} \\
\hline & $\%$ & $\pm \mathrm{K}$ & $\%$ & $\pm \mathrm{K}$ & $\%$ & $\pm \kappa$ & & \\
\hline Боровський & - & - & 5,39 & 0,98 & - & & 4,41 & 9,80 \\
\hline Велетень & - & - & 5,39 & \begin{tabular}{|l|}
1,96 \\
\end{tabular} & - & & 3,43 & 8,82 \\
\hline Дохідний & 0,98 & $-1,0$ & - & & 0,00 & $-1,96$ & 1,96 & 2,94 \\
\hline $\begin{array}{l}\text { Клиновид- } \\
\text { ний }\end{array}$ & 6,86 & 4,9 & - & & 0,00 & $-1,96$ & 1,96 & 8,82 \\
\hline $\begin{array}{l}\text { Краснолис- } \\
\text { тий }\end{array}$ & 4,90 & $-4,4$ & - & & 5,39 & $-3,92$ & 9,31 & 19,61 \\
\hline $\begin{array}{l}\text { Лозівський } \\
\text { булавовид- } \\
\text { ний }\end{array}$ & - & & 0,00 & $-0,49$ & & & 0,49 & 0,49 \\
\hline \begin{tabular}{|l|} 
Лозівський \\
шаровидний \\
\end{tabular} & 4,41 & 1,5 & & & 0,98 & $-1,96$ & 2,94 & 8,33 \\
\hline $\begin{array}{l}\text { Олімпійсь- } \\
\text { кий }\end{array}$ & & & 6,37 & 0,49 & & & 5,88 & 12,25 \\
\hline Пірожок & & & 2,94 & 0,98 & & & 1,96 & 4,90 \\
\hline $\begin{array}{l}\text { Превосход- } \\
\text { ний-2 }\end{array}$ & & & 0,49 & 0,49 & & & 0,00 & 0,49 \\
\hline Серебристий & & & 0,00 & 0,00 & & & 0,00 & 0,00 \\
\hline Харків-4 & 7,84 & 2,0 & - & & 9,80 & 3,92 & 5,88 & 23,53 \\
\hline Всього & 25,00 & - & 20,59 & & 16,18 & - & 38,24 & 100,0 \\
\hline Середнє & 5,00 & 1,80 & 2,94 & $-0,30$ & 3,36 & 0,16 & 3,20 & - \\
\hline $\begin{array}{l}\text { Середнє, за } \\
\text { винятком } \\
\text { сортів, які } \\
\text { випали }\end{array}$ & 5,00 & 0,81 & 5,02 & 0,83 & 4,04 & $-0,15$ & 4,19 & - \\
\hline
\end{tabular}

Застосування цих препаратів сприяло вищій приживлюваності відносно контролю. Найвищий ефект від впливу препарату "Grandis" був для сорту 'Клиновидний'. Використовуючи препарат "Grandis", перевищення контролю також встановлено для таких сортів, як 'Харків-4' та 'Лозівський шаровидний'. Дещо нижчий ефект був для сортів у разі попереднього замочування живців. Поряд із цим практично усі сорти позитивно відреагували на попереднє замочування у воді.

Сорти, які характеризувалися загибеллю усіх живців "Превосходний-2", "Серебристий" та "Лозівський булавовидний", не були представлені в усіх варіантах. Тому було розраховано середні значення без урахування цих сортів. За розрахунковими даними, найефективнішим виявилося попереднє замочування у воді та використання препарату "Grandis". Наявність збереженого листа та розвинених бруньок сприяли росту калюсу (рис. 2).

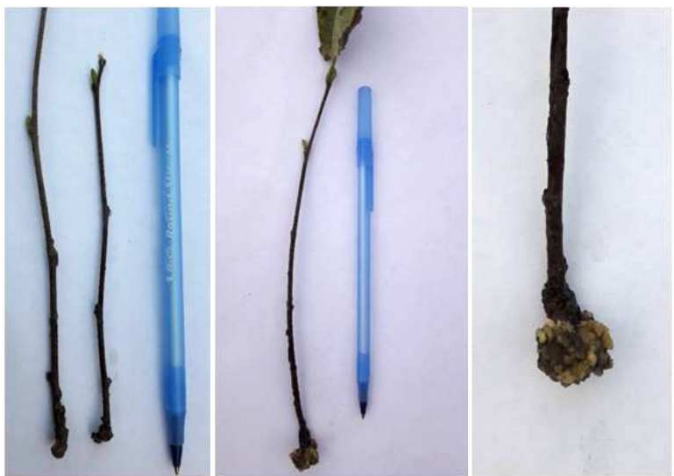

Рис. 2. Особливості формування калюсу у живців фундука внаслідок формування 1-2 бруньок (а), а також збереженості листка та формування бруньок (б, в) в умовах теплиці ДП "Гайсинське ЛГ", 2017

За результатами проведених досліджень встановлено, що приживлюваність більшою мірою залежала від сорту. Удосконалення технології зеленого живцювання шляхом використання відповідних стимуляторів росту або певної підготовки (замочування) живців може тільки певною мірою підвищити рівень виходу садивного матеріалу.

Висновки. Найвищою приживлюваністю у теплицях із туманним зрошенням вирізнялися такі сорти фундука, як 'Харків-4' (64 \%), 'Краснолистий' (53 \%) та 'Олімпійський' (50\%). Низьку приживлюваність мали сорти 'Превосходний-2', 'Лозівський булавовидний' та 'Дохідний' (2-8 \%). Повністю загинули живці сорту 'Серебристий'. Виявлено позитивний вплив попереднього замочування живців у воді на більшість сортів фундука. Найбільший вплив препарату "Grandis" був на такі copти фундука: 'Клиновидний', 'Лозівський шаровидний' та 'Харків-4'. Препарат "Чаркор" мав позитивний вплив тільки на сорт 'Харків-4'.

\section{Перелік використаних джерел}

Alihanova, A. A. (2009). Estestvennoe vegetativnoe vozobnovlenie leshchiny obyknovennoy i potencial $\mathrm{k}$ regeneracii ee isolirovanykh structu. Abstract of Candidate Dissertation for Biology Sciences (03.00.12 - Fiziologiya i biohimiya rasteniy). Mahachkala. [In Russian].

Balabak, O. A. (2015). Ahrotechnicny zahody pryskorenogo vyroshchuvannya sadyvnoho materialy sortiv $\mathrm{i}$ form funduka (Corylus domestica kosenko et opalko) metodom zelenoho zhyvtsyvanny. [Agrotechnological modes of accelerated raising of hazelnut forms and cultivars (Corylus domestica kosenko et opalko) planting stock by the green cutting method]. Naukovi dopovidy Natsionalnoho universytety bioresyrsiv $i$ pryrodokorystyvannya Ukrainy, 7. [In Ukrainian].

Bassil, N. V., Probesting, M. V., Moore, L. W., \& Limghfoot, D. A. (1991). Propagation of hazelnut stem cuttings using agrobacterium rhizogenes. HortScience. Oregon State University, 26(8), 1058-1060.

Chopyk, V. I., Dydchenko, L. H., \& Krasnova, A. N. (1983). Dycorastushchie poleznye rasteniya. Kyiv: Nauk. dumka. 400 p. [In Russian].

Ivanova, Z. Ya. (1982). Biolohycheskie osnovy $i$ priyomy vegetativnoho razmnozhenia drevesnyh rasteniy steblevimy cherenkamy. Kiev: Nauk. dumka. 288 p. [In Russian].

Kolchanova, O. V., \& Los, S. A. (2014). Minlyvist morpholohychnikh oznak serezhok sortiv funduka ukrainskoi selectsii. [Variability in morphological features of catkins of hazelnut varieties of Ukrainian selection]. Lisivnytstvo $i$ ahrolisomelioratsiya, 125, 115-121. [In Ukrainian].

Kudasheva, R. F. (1965). Razvedenie i selekciya leshchiny i funduka. Moscow: Lesnaya prom. 131 p. [In Russian]. 
Los, S. A. (1992). Osobennosty biologii plodonosheniya funduka v usloviyah severo-vostochnyh rajonov Ukrainy. Doctoral Dissertation for Agricultural Sciences (06.03.01 - Forest crops and phytomelioration). Kharkov. 21 p. [In Russian].

Los, S. A. (1994). Osoblyvosti rozvytku plody sortiv funduka ukrainskoi selectsii. [Features of development nuts of hazelnuts varieties of Ukrainian selection]. Lisivnytstvo i ahrolisomelioratsiya, 90, 44-46. [In Ukrainian].

Pinchuk, A. P., \& Lihanov, A. F. (2016). Vplyv stymulyatiriv rosty na histohenez coreniv napivzderevyanilyh zhyvtsiv decoratyvnih cushchiv [The influence of growth stimulators on the roots histogenesis of ornamebtal srubs semi-hardwood cuttings]. Naukoviy visnyk NuBiP, seriya Lisivnytstvo ta decoratyvne sadivnytstvo, 238, 155-161. [In Ukrainian].

Shchepotev, F. L., Richter, A. A, Pavlenko, F. A., et al. (1978). Orechoplodnye lesnye cultury. Moscow: Lesnaya prom. 256 p. [In Russian].

Sobchenko, V. (2004). Rozmnozhennya decoratyvnyh roslyn metodom shcheplennya svizhozrizanymy zhyvtsyamy $\mathrm{v}$ period spokoyu [Inoculation of decorative plants in early-spring time]. Visnyk Lviv un-ty. Seriya biolohychna, 36, 175-185. [In Ukrainian].

Tsyhankova, V. A., Ponomarenko, S. P., \& Halkin, A. P. (2012). Rehulyator rosty "Charkor" yak inductor nakopychennya biomasy $\mathrm{v}$ culturah borodatyh coreniv cykoriyu - producentiv polifructantiv. [The growth regulator "Charkor" as inductor of biomass accumulation in the chicory "hairy roots" cultures - producers of polyfructans]. Biotehnolohyiyat, 5(4), 65-73. [In Ukrainian].

Vanycheva, S. G. (1989). Recomandatsii po razmnozheniyu funduka $i$ leshchiny zelyonym cherenkovaniem. Ivanteevka: Gos. comitet SSR po lesy. 40 p. [In Russian].

Vasylyuk, O. M., Hrytsenko, O. M., \& Vasylyuk, P. V. (2008). Vplyv rehulyatoriv rosty na actyvnist fermentiv pereaminyvannya $\mathrm{v}$ lysti ta corenyah Salix alba. [Influence of growth regulators on activity of transamination enzymes in leaves and roots of Salix alba]. Visnyk Dipropetrovskoho universytety. Biolohiya. Ekolohoya, 16(1), 34 40. [In Ukrainian].

ГП "Винничкая лесная научно-исследовательская станиия" УкрНИИЛХА, г. Виннича, Украина

\section{РЕЗУЛЬТАТЫ ПРИЖИВАЕМОСТИ СОРТОВ ФУНДУКА ПРИ ЗЕЛЕНОМ ЧЕРЕНКОВАНИИ В ТЕПЛИЦАХ С ТУМАННЫМ ОРОШЕНИЕМ В УСЛОВИЯХ ВИННИЦКОЙ ОБЛАСТИ}

Исследованы особенности приживаемости сортов фундука путем зеленого черенкования. Использовано 12 сортов фундука украинской селекции, которые отличались по морфологическим признакам и уровню плодоношения в условиях дендропарка Харьковского национального аграрного университета. Исследованы сорта: 'Боровской', 'Великан', 'Доходный', 'Клиновидный', 'Краснолистный', 'Лозовский булавовидный', 'Лозовской шаровидный', 'Олимпийский', 'Пирожок', 'Превосходный-2', 'Серебристый', 'Харьков-4'. Оценено влияние веществ-активаторов ризогенеза: "Чаркор" (0,30 \% раствор) и "Grandis" (0,33 \% раствор). Варианты исследований также включали предварительное замачивание черенков в воде и непосредственное нарезание черенков перед закладкой в теплице. По результатам проведенных исследований установлена зависимость степени приживаемости фундука при зеленом черенковании от сорта. Самый высокий уровень ризогенеза выявлено у сортов 'Харьков-4' (64 \%) и 'Краснолистный' (53 \%). Несколько ниже приживаемость и ризогенез были у таких сортов, как: 'Боровской', 'Великан' и 'Олимпийский' (40-50 \%). Низкая сохранность была у сортов 'Превосходный-2', 'Лозовский булавовидный' и 'Доходный' (2-8 \%). Полностью погибли черенки сорта 'Серебристый'. Высшая приживаемость при использовании препарата "Grandis" была у таких сортов, как 'Клиновидный' и 'Лозовский шаровидный'. Отмечено положительное влияние препарата "Чаркор" на сорт 'Харьков-4'. Большинство сортов положительно отреагировали на предварительное замачивание черенков в воде.

Ключевые слова: ризогенез; фундук; сорт; активаторы роста; зеленое черенкование.

O. V. Kolchanova

SE "Vinnitsa Forest Research Station", Vinnitsa, Ukraine

\section{RESULTS OF SURVIVAL OF HAZELNUT VARIETIES WITH GREEN STEM CUTTING IN GREENHOUSES WITH FOGGY IRRIGATION IN VINNYTSIA REGION}

The authors have studied the features of hazelnut rooting using green stem cutting. We used 12 hazelnut varieties of Ukrainian selections which have different morphological peculiarities and nuts productivity in Deontological Garden of Kharkiv National Agricultural University (Eastern part of Ukraine). We have investigated such hazelnut varieties as 'Borovskiy', 'Veleten', 'Dohidniy', 'Klynovydniy', 'Krasnolystiy', 'Lozivskiy bulavovydniy', 'Lozivskiy sharovydniy', 'Olimpiyskiy', 'Pirozhok', 'Prevoshodniy-2', 'Serebrystiy', and 'Kharkiv - 4'. Therefore, the purpose of the research was to investigate Ukrainian breeding hazelnut varieties rooting ability and develop the most optimal technological approaches to green stem cutting in greenhouse. In the course of our study we estimated the impact of activators of such rhizogenesis substances as "Charkor" (concentration of $0.30 \%$ ) and "Grandis" (concentration of $0.33 \%$ ). Research option included previously soaking in water and cutting of green stems before lying in the greenhouse. We used substrate of humus part of gray forest soil covered by layer of sand $3-5 \mathrm{~cm}$ thick. Estimation of green stem cutting survival was made in the end of vegetative season. We determined parameters of stem cutting survival to be as follows: $1-$ preserved green old leaf without buds; 2 - preserved green old leaf with one bud; 3 - preserved green old leaf and two buds; 4 - the presence of only one bud without old leaf; 5 - the presence of two and more buds without an old leaf. We indicated different intensity of rotting stem cutting according to hazelnuts varieties. The highest level of rhizogenesis was shown by such varieties as 'Kharkiv-4' (64\%) and 'Krasnolystiy' (53\%). The varieties of 'Borovskiy', 'Veleten' and 'Olimpiyskiy' had less survival ability (40$50 \%$ ). Even less survival was present by such varieties as 'Prevoshodniy-2', 'Lozivskiy bulavovydniy' and 'Dohidniy' (2-8 \%). The green stem cuttings of 'Serebrystiy' were dead. We indicated a positive impact of "Grandis" substances on such varieties as 'Klynovydniy' and 'Lozivskiy sharovydniy'. "Charkor" substances had a positive impact on varieties 'Kharkiv-4'. Most varieties had a positive reaction on previous soaking in water.

Keywords: rhizogenesis; hazelnut; variety; growth activators; green stem cutting. 